\section{Just one research council?}

\section{London}

A RADICAL overhaul of the mechanisms for funding civil scientific research in Britain is needed, according to a review group set up by the Advisory Board for the Research Councils (ABRC), which advises the government on allocation of the science budget.

In a confidential report to the $\mathrm{ABRC}$, the group recommends that the five research councils be replaced with one, to be called the National Research Council (NRC). With replacement of the ABRC by the NRC's governing council, the responsibility for all aspects of science spending would be vested in a single organization. The review group, chaired by Richard Morris, deputy chairman of the ABRC, has reported its conclusions to the ABRC, which is now waiting for responses from the research councils. If the ABRC accepts the report, it will then need the approval of the secretary of state. Implementing the reforms could take two years; as each council was set up by royal charter, legislation or further charters would be needed.

The problem which prompted the review was the overlap in responsibilities for the biological sciences. Biotechnology, for example, is funded through four research councils, and attempts at coordination have been unsuccessful, partly due to the problem of reconciling different styles of operation. The Biotechnology Advisory Group, set up in 1985 to improve coordination, is perceived as being substantially ineffective, says the report, and inter-council relationships are now so bad that suggestions by one are regarded with suspicion by others. Genetics is also singled out as an area in which there is significant overlap between councils, mainly the Science and Engineering Research Council (SERC) and the Medical Research Council (MRC).

The result is duplication of research, as well as neglect of research for which no council claims responsibility. Researchers in universities and industry are unsure which council to contact. And for research

problems that involve more than one council, a coordinated reaction is slow.

The review group rejected one possible solution: the formation of a council for non-medical biological sciences. This council would have to cooperate closely with SERC and the problem of cooperation between councils with different styles of operation would remain.

Instead it recommends formation of an NRC with six divisions (see diagram). The MRC would remain essentially as it is now, though some research might be transferred to the biology and environment division, or vice versa. The Economic and Social Research Council (ESRC) would also retain its current responsibilities.

Boundaries within one research council would be "more permeable" than those between the present research councils, says the report. Coordination of resources would be easier and there would be flexibility in allocation of resources. A single council would also mean significant savings in administration costs. And it would create a focal point for international links.

The governing council of the new NRC would have much greater control over the nation's science budget than the ABRC does at present. It would set priorities, allocate funds and be answerable only to the Secretary of State for Education and Science and to parliament. Although the ABRC has influence through its advice, it lacks the authority to ensure its recommendations are carried through, and is not accountable for the consequences of its advice.

On the NRC council would be the NRC director-general, the principal executive officer; a non-executive part-time chairman; the division directors; the chief scientist at the Cabinet Office; the chief executive of the Universities Funding Council; and eight independent members from industry or higher education. (These, as well as the chairman, would be appointed by the Secretary of State.) The council would have to produce a national strategy for science and engineering every five years and monitor progress against

National Research Council

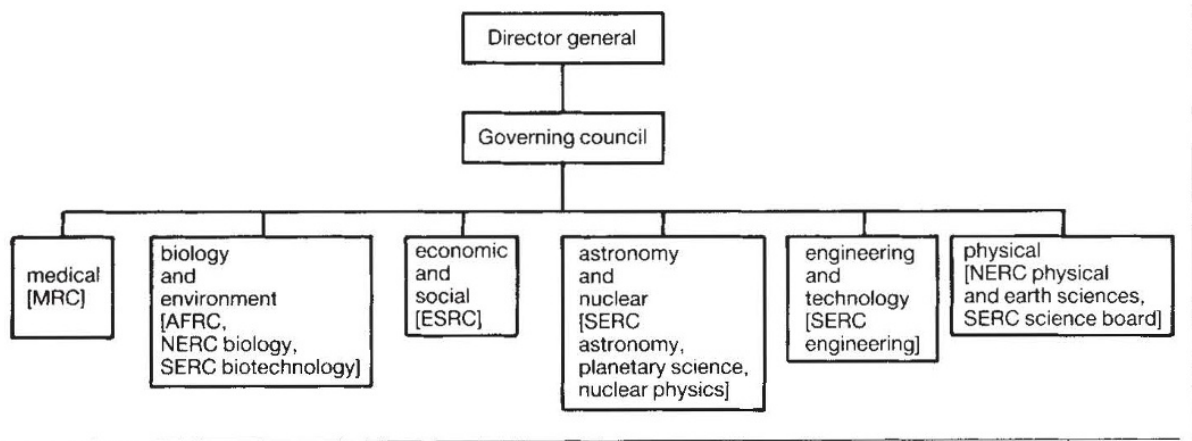

\section{Bottom of the spending league}

\section{Dublin}

THE Irish government is running hard just to stay still in its support of science and technology. The Irish science and technology agency (Eolas) announced earlier this month that total spending in Ireland on research and development increased by 10 per cent between 1985 and the following year (the latest for which figures are available), but that the total remains a fixed proportion of gross domestic product at $\mathbf{0 . 9}$ per cent.

This puts Ireland firmly near the bottom of the research spending league, both in Europe and in a wider framework. Eolas notes that annual research and development spending in Ireland amounts to the equivalent of IR£47 per head, compared with IR£111 in Denmark, IR£205 in Britain and IR£360 in the United States.

Part of the trouble is that only 18 per cent of the government's science and technology budget is spent on research, but Eolas says that only 6.4 per cent of Irish manufacturing companies spend money on research and development of any kind, and that $\mathbf{1 7}$ foreign-owned companies account for two thirds of the country's spending in the field. Mary Mulvihill

\section{the plan.}

Senior positions in the NRC should be occupied by scientists with management training or experience, says the report, and the new council should encourage business schools to establish courses in management of research.

The idea of a single research council has been criticized in the past. The dangers are that it would be too large and remote from researchers. Policy errors in grant allocation would have more serious consequences than at present, and a reduction in the number of sources of funds might mean fewer opportunities for applicants. But the review group dismisses the criticisms. "Each of these potential dangers is avoidable", it says, but exactly how, it does not say.

As an immediate interim measure, pending formation of the NRC, the report recommends that the $\mathrm{ABRC}$ appoint two planning directors, for the biological and physical sciences, for drawing together the relevant elements of the AFRC (Agricultural and Food Research Council), NERC (Natural Environment Research Council), SERC and, if appropriate, the MRC to form the new divisions.

It also proposes giving influence within the NRC to individual 'coordinators', in areas where "high-powered individuals" are more effective than committees, such as coordination of biotechnology, development of policies for training research manpower and forging links with the European Community. Christine McGourty 